\title{
Qabaqc1l Elektron Elm Layihələrinin Proqram Təminatının Spesifik Xüsusiyyətləri
}

\author{
Təhmasib Fətəliyev, Nərgiz Verdiyeva \\ AMEA İnformasiya Texnologiyaları İnstitutu, Bakı, Azərbaycan \\ depart3@iit.ab.az
}

\begin{abstract}
Xülasə- Yüksək məhsuldarlıqlı hesablamalar və müvafiq e-elm infrastrukturu müasir elmi-tədqiqat fəaliyyətinin zəruri tərkib hissələridir. Onların əsasını aparat və proqram təminatlarının yaradılması təşkil edir. Məqalədə e-elmin formalaşmasında proqram vasitələrinin rolu, qabaqcıle-elm layihələri və onların proqram təminatının xüsusiyyətlori araşdırılmışdır. Göstərilmişdir ki, açıq kodlu tətbiqi proqram vasitələrindən istifadə etməklə milli e-elmin daha səmərəli inkişafına nail olmaq olar.
\end{abstract}

Açar sözlor-e-elm, qabaqcıl e-elm layiholori, e-xidmotlor, proqram tominat, elmi totbiq vo alotlor

\section{GİRIŞ}

Müasir dövrdə E-Azərbaycanın tərkib hissəsi olan e-elm sahəsində aparılan tədqiqatlar və alınmış praktiki nəticələr mühüm əhəmiyyət kəsb edir və perspektiv elmi istiqamət kimi inkişaf etdirilir [1]. E-elmin reallaşması kommunikasiyalaşdırma, kompüterləşdirmə, şəbəkələşdirmə, informasiyalaşdırma və virtuallaşma kimi beş səviyyə üzrə həyata keçirilir. $\mathrm{Bu}$ səviyyələrin hər biriisə müxtəlif təyinatlı texniki və proqram təminatı ilə xarakterizə olunur.

Təqdim edilən işdə e-elmin proqram təminatının spesifik xüsusiyyətləri tədqiq olunmuş və e-elmin formalaşması və inkişafinda onun perspektivlərinin müəyyənləşdirilməsi üzrə müvafiq tövsiyələr verilmişdir.

\section{E-ELMIN FORMALAŞMASINDA PROQRAM TOMINATININ ROLU}

On yeni informasiya-kommunikasiya texnologiyalarının (IKT) və onların əsasında yaradılan sistemlərin inkişafı eelmin proqram təminatının işlənilməsi, müşayiət edilməsi və təkmilləşdirilməsi məsələlərinə yenidən baxılmasını aktual bir probem kimi zəruri edir və proqram mühəndisliyinin tərkib hissəsi olaraq daima təkmilləşdirilməsini qarşıya qoyur.Elm və texnikanın, həmçinin e-elmin proqram təminatının yaradılması və tətbiq edilməsi proqram mühəndisliyininvacib sahəsidir. Məlumdur ki, proqram təminatı informasiyanın emalı sistemi proqramları və onların istifadəsi üçün zəruri olan proqram sənədləri toplusudur.

Qeyd edək ki, respublikada uğurla formalaşmaqda olan eelm mürəkkəb infrastruktura malikdir və elmi qurumları tam əhatə etmək vəzifəsi daşıyır. Onu həll etdiyi məsələlərin təyinatına görə şərti olaraq şəbəkə və hesablama infrastrukturu, informasiya təminat,, Big Data, elmmetrik təhlillər, e-xidmətlər, vətəndaş elmi və s. kimi müxtəlif altsistemlərə ayırmaq olar.Texniki, riyazi, informasiya, lingvistik, təşkilatı və metodoji təminatları ilə yanaşı proqram vasitələri də bu altsistemlərin formalaşmasında mühüm rol oynayır.

E-elmin proqram təminatını ənənəvi olaraq sistem, tətbiqi və instrumental hissələrə ayırmaq olar.Sistem proqram təminatı sistemin resurslarının effektiv idarə edilməsini təmin edən proqramlar kompleksidir. Tətbiqi proqram təminatından forqli olaraq, sistem proqram təminatı konkret tətbiqi məsələləri həll etmir, sadəcə digər proqramların işini təmin edir, sistemin texniki resurslarını idarə edir vo s.Tətbiqi proqram təminatı istifadəçilərin müxtəlif məsələlərinin həlli üçün nəzərdə tutulan ayrı-ayrı tətbiqi proqramlar və onların paketləridir.İnstrumental proqram təminatı isə proqramların layihələndirilməsi, işlənməsi və müşayiət olunması üçündür. $\mathrm{Bu}$ proqram təminatı yeni proqramların və proqram komplekslərinin işlənməsi üçün nəzərdə tutulmuşdur. Misal olaraq Globus layihəsi çərçivəsində e-elmin əsasını təşkil edən qrid layihələrinin həyata keçirilməsi üçün hazırlanmış instrumental proqram vasitələrini nəzərdən keçirək[2]. Bunlar Globus Toolkit proqram vasitələri toplusunu təşkil edir və tam funksional qrid sistemi yaratmağa imkan verir. Globus Toolkit vasitələri sistemin zəruri hissələrini həyata keçirən proqram komponentləridir:

- GRAM (Globus Resource Allocation Manager) proseslərin yaradılması və silinməsinə cavab verir.

- MDS (Monitoring and Discovery Service) - sistem haqqında informasiyanın təqdim edilməsi yollarını təmin edir. $\mathrm{Bu}$ informasiya sistemin konfiqurasiyası və vəziyyəti, həm də onun ayrı-ayrı resursları (resursun tipi, disklərdəki boş yerlər, prosessorların sayı, yaddaşın həcmi, məhsuldarlıq və s.) haqqinda ola bilər.

- GSI (Globus Security Infrastructure) - verilənlərin şifrələnməsini, həmçinin autentifikasiya və avtorizasiya da daxil olmaqla təhlükəsizliyini təmin edir.

- GASS (Global Access to Secondary Storage) paylanmış mühitdə böyük həcmdə verilənlərin saxlanılması və onlara çıxışı təmin edir.

- Globus kitabxanalarl- tətbiqi proqramlar, həmçinin Globus Toolkit komponentləri tərəfindən qovşaqların şəbəkədə heterogen mühitdə qarşılıqlı əlaqəsi üçün istifadə olunur.

Təkcə instrumental proqram təminatı timsalında təqdim olunmuş bu nümunə e-elmin mürəkkəb bir sistem olmasını və onun formalaşmasında, istismarında və inkişafinda proqram mühəndisliyinin mühüm rol oynamasını təsdiq edir. 


\section{QABAQCIL E-ELM LAYİHӘLӘRİ VӘ ONLARIN PROQRAM TOMINATININ XÜSUSIYYOTLӘRI}

E-elmin və onun formalaşmasında proqram mühəndisliyinin müasir inkişaf tendensiyaları dünyada həyata keçirilən bir sira elektron tədqiqat infrastrukturlarının yaradılması layihələrində özünü göstərir. Belə ki, açıq elmi tədqiqatların aparılması məqsədilə ABŞ-ın Milli Elm Fondunun TeraGrid layihəsi çərçivəsində dünyada ən böyük paylanmış kiberinfrastrukturlardan biri formalaşdırılır[3]. TeraGrid vasitələrinə tələbatı olan elmi istiqamətlərə dəstək, e-elm metodlarından istifadə edən elmi cəmiyyətlərin genişləndirilməsi və girış interfeyslərinin işlənməsi zamanı ayr1-ayr1 qrid infrastrukturları və informasiya xidmətlərinin uyğunluğunun təmin olunmasılayihənin əsas məqsədləridir.

Yaponiyanın NAREGI (National Research Grid Initiative) layihəsi böyük miqyaslı tətbiqlərdə istifadə üçün milli qrid infrastrukturunun aralıq qatının proqram təminatının işlənməsinə yönəlmişdir[4].

Son onillikdə e-elmin instrumental imkanlarının artması əsas inkişaf tendensiyalarındandır. Bu da elmi eksperimenlər nəticəsində alınan böyük həcmli verilənlər (Big Data) və onların bulud və ya qrid texnologiyaları çərçivəsində emalı üçün ötürülməsinin zəruriliyi, tədqiqatçıların böyük ölçülü verilənlərə və unikal elmi avadanlıqlara (güclü elektron mikroskoplara, elementar zərrəciklərin sürətləndiricilərinə, tibbi avadanlıqlara və s.) uzaqdan keçidinin təmin edilməsi, ərazicə paylanmış elmi təşkilatlar tərəfindən layihələrin birgə həyata keçirilməsi ilə xarakterizə olunur.

E-elmin inkişafının vacib xarakterik digər tendensiyası tədqiqat işinin xarakterini tamamilə dəyişdirən elmi-tədris kompüter şəbəkələrinin (National Research and Education Network - NREN) yaradılması olmuşdur. Bu şəbəkələr alimlərə müxtəlif təşkilatlar tərəfindən dəstəklənən və müxtəlif elm sahələrinə aid olan paylanmış resurslardan birgə və koordinasiya edilmiş şəkildə istifadəni, həmçinin hesablama resursları və verilənlər arxivləri kimi əsas tədqiqat alətlərinə keçidi asanlaşdırır. İnnovativ NREN-ə misal olaraq Avropanın 10 mindən çox təşkilatı üzrə 50 milyondan çox istifadəçini əlaqələndirən və elementar zərrəciklər fizikası və energetika, bioinformatika, genomika və tibb, seysmologiya, meteorologiya, iqlim dəyişmələri və ətraf mühitin mühafizəsi kimi sahələrdə elmi tədqiqatları dəstəkləyən ümumavropa GEANT -tı[5] göstərmək olar. Dünyada ən böyük elmi-tədris şəbəkələrindən biri olan Avropanın elmi mühiti infrastrukturu GEANT 100-dən çox milli NREN-ləri birləşdirərək 500 Gb/san sürətlə verilənlərin ötürülməsini həyata keçirir. Azərbaycanın elm və təhsil şəbəkələrinin milli operatoru AzScienceNet də həmin infrastruktura daxildir.

Yuxarıda təqdim olunmuş və ümumiyyətlə, e-elm layihələrinin yerinə yetirilməsində proqram vasitələrinin rolunu dünyanın qabaqcıl $E G I$ və $N e S I$ layihələri timsalında təsəvvür etmək olar.

Avropa qrid infrastrukturu EGI. Avropanın elmi təşkilatları və universitetlərinin böyük hesablama resurslarının vahid qrid infrastrukturunda birləşdirilməsini həyata keçirən Avropa qrid infrastrukturu (European Grid InfrastructureEGI) qlobal layihələrdəndir[6]. O, istifadəçilərə 700000-dən çox məntiqi prossessor və ümumilikdə $500 \mathrm{~PB}$ yaddaşa malik disk və lent qurğuları təqdim edir. Həmin resursları dünyanın 56 ölkəsinin 350 verilənlərin emalı mərkəzi təmin edir. $\mathrm{Bu}$ layihə qrid sahəsində başlanan avropa layihələrinin inkişafına əsaslanır.

EGI-nin inkişaf mərhələlərinı, e-xidmətlərini və proqram vasitələrini daha ətraflı nəzərdən keçirək.Belə ki, CERN-nin Large Hadron Collider-ində alınmış eksperimental verilənlərin emalı üçün 1999-cu ildə ilk paylanmış hesablama qridi yaradılmışdır. 2001-ci ilin yanvarında başlanan Avropa DataGrid layihəsi qrid texnologiyalarının tədqiqi və inkişafına yol açmıs və yüksək enerji fizikası, Yer kürəsinin müșahidəsi və bioinformatikakimi tədqiqat sahələrində uğurla tətbiq edilmișdir. 2004-cü ilin martından başlanan EGEE-nin (Enabling Grid for E-sciencE) iki illik fazalarla həyata keçirilən üç layihəsi uğurlu nəticələnə biləcək gələcək inkişafi öz üzərinə götürdü. European Grid Initiative Design Study layihəsi 2007-ci ilin sentyabrından 2009-cu ilin dekabrına kimi davam etmişdir. O, Avropa səviyyəsində şəbəkənin fəaliyyəti və inkişafının daimi təşkili üçün konseptual və logistik baza yaratmışdır. Sonralar EGI.eu adlandırılan EGI Foundation 2010-cu ilfevralın 8-do Avropa tədqiqat cəmiyyətlərini və onların beynəlxalq əməkdaşlarını dəstəkləmək üçün dayanıqlı ümumavropa infrastrukturu Avropa QridInfrastrukturunu koordinasiya etmək və ona kömək məqsədilə yaradılmışdır. EGI -InSPIRE layihəsi isə indiki və gələcək elmi cəhdlərin tələblərinə cavab verən qüsursuz bir sistem yaratmaq məqsədi ilə EGI-nin fəaliyyətini 2014-cü ilin dekabrına kimi dörd il ərzində dəstəkləmişdir. 2015-ci ilin mart ayında hesablama, yaddaş, verilənlər, bilik və ekspertiza üçün Açıq elmi cəmiyyətlərin yaradılmasını sürətləndirmək, vahid avropa federasiyasının imkanlarını genişləndirmək üçün EGI-Engage layihəsi başlamışdır.

Beləliklə, bu layihələrin davamı olan Avropa qrid infrastrukturu 2016-c1 ildə sadəcə EGI kimi tanınmağa başlanmışdır. EGI alimlərə, çoxmillətli layihələrə və tədqiqat infrastrukturlarına dəstək üçün aşağıdakı elektron xidmətləri təklif edir:

\section{Hesablama:}

a) Cloud Compute - hesablama resurslarına tam nəzarət tələbi ilə virtual maşınların işə salınması;

b) Cloud Container Compute BETA - yüngül çəkili virtuallaşdırılmış mühitdə iş;

c) High-Throughput Compute - böyük ölçülü verilənləri təhlil etmək üçün minlərlə hesablama məsələlərinin icra edilməsi;

\section{Yaddaş və verilənlər:}

a) Online Storage - fayl və meta verilənlərin qlobal miqyasda saxlanılması, birgə istifadəsi və əlyetənliyi.

d) Archive Storage - təhlükəsiz mühitdə uzunmüddətli və gələcəkdə istifadə üçün verilənlərin ehtiyat nüsxələrinin yaradilması.

\section{Təlim:}


a) FitSM training - İT xidmətlərin idarə edilməsi mexanizmlərinin öyrədilməsi.

e) Training infrastructure - təlim və təhsil üçün ayrılmış kompüterlər və verilənlərin saxlanması sistemləri.

EGI-nin aşagıda göstərilmiş elmi tətbiq və alətlərini nəzərdən keçirək.

$\checkmark$ HADDOCK - protein və digər biomolekulkompleksləri modelləşdirmək üçün təqdim olunan hesablama alətləridir. Onun vasitəsi ilə yerinə yetirilən minlərlə hesablama məsələsindəEGI-nin yüksək məhsuldarlıqlı hesablama xidmətindən istifadə edir. $\mathrm{Bu}$ günə qədər, onunla 8000-dən çox alimin 130000-dən artıq sifarişi emal edilmişdir ki, bu da EGI infrastrukturunda ildə 8 milyon iş yeri deməkdir. HADDOCK-un tələb etdiyi hesablama resurslarını Belçika, Almaniya, İtaliya, Polşa, Portuqaliya, İspaniya, Birləşmiş Krallıq və digər beynəlxalq təşkilatların milli einfrastrukturlarıtəmin edir. Yeddi federativData mərkəz HADDOCK xidmətlərinin davamlılığını təmin etmək üçün 75 milyon saat hesablamavaxtı və 50 TB-dan çox yaddaş sərf etmişdir.

$\checkmark$ NBIS alotlər dosti - həyat elmləri tədqiqatçıları üçün bioinformatika alətləridir. Bioinformatika üçün aşağıdakı onlayn elmi tətbiqlər təqdim edilir:

- Pcons.net 3D: protein strukturlarının proqnozlaşdırılması üçün meta-server;

- $\quad$ PconsC2/PconsC3: ixtiyari ölçülü ailələr üçün dəqiq əlaqələrin proqnozlaşdırılması;

- $\quad$ SCAMPI:konkret şərtlər daxilində membran protein topologiyasının proqnozlaşdırılması;

- BOCTOPUS: transmembran proteinlərin topologiyaSının proqnozlaşdırılması;

- ProQ3:modelinkeyfiyyətininqiymətləndirilməsi;

- TOPCONS:membran protein topologiyası vo siqnal peptidinin consensus proqnozlaşdırılması.

NBIS EGI-nin hesablama və yaddaş xidmətlərindən istifadə edir. Bu xidmətlər üçün resurslar INFN-Bari (İtaliya), IN2P3-IRES (Fransa) və TUBITAK (Türkiyə) provayderləri tərəfindən təmin edilir.

$\checkmark$ DisVis- biomolekullar arasındakı məsafə məhdudiyyətləri ilə müəyyən edilmiş qarşılıqlı əlaqələrin vizualizasiyası və kəmiyyətin müəyyən olunması üçün nəzərdə tutulmuş proqram tominatıdır.

$\checkmark$ Chipster - verilənlərin analizi üçün istifadə olunan istifadəçi yönümlü, açıq kodlu proqram təminatıdır. Ona 360dan çox analiz aləti və böyük sayda etalon genom daxildir. İstifadəçilərə avtomatik analizin işçi proseslərini yadda saxlamaq, birgə istifadəetmək və interaktiv rejimdə verilənlərin vizualizasiyası imkanları verilir.

$\checkmark$ VIP (Virtual Imaging Platform)- tibbi modelləşdirmə və təsvirlərin virtual emalı üçün nəzərdə tutulmuşdur və aşağıdakılarıtəqdim edir:
- GATE- emissiya və kompüter tomoqrafiyasının, şüa terapiyası üçün optiki vizuallaşdırma eksperimentlərinin modelləşdirilməsi;

- Freesurferand FSL- neyrovizualizasiya verilənlərinin analizi və $\mathrm{s}$.

Təkcə, 2017-ci ilin yanvarına olan məlumata görə VIP-də 990 istifadəçi qeydiyyatdan keçmişdir və onların bu platformadan istifadə vaxtı ayda 30 il ətrafında olmuşdur.

$\checkmark$ Peachnote - musiqinin qiymətləndirilməsi və analiz üçün axtarış sistemidir. Təyinatına görə ilk olan bu sistemə gün ərzində dünyadan on minlərlə istifadəçi müraciət edir. İstifadəçilərə musiqi verilənlərinə çıxıș üçün istifadə olunan bulud resursları CESNET MetaCloud və FZI provayderləri tərəfindən təmin edilir.

Qeyd olunanlarla yanaşı EGI elmi fəaliyyət və biznes üçün təqdim olunan xidmətlərin koordinasiyanı asanlaşdırmaq və Federasiyada birgə fəaliyyətin səmərəliliyini artırmaq üçün aşağıdakı daxili xidmətləri təklif edir:

- Mühasibat;

- Oməliyyatların koordinasiyası və dəstəyi;

- Elmi cəmiyyətlərin koordinasiyası;

- Kommunikasiya;

- Layihələrin idarə olunması və planlaşdırılması;

- Dəstək;

- Xidmətlərin monitorinqi;

- Test edilmiş proqram təminatı və bazalar;

- Oməliyyat alətləri;

- Təhlükəsizliyin koordinasiyası;

- ITT xidmətlərin idarə olunmasının koordinasiyası;

- Texniki koordinasiya;

- Strategiya və siyasətin işlənilməsi;

- Verilənlərbazasınınkonfiqurasiyasi;

- Birgə əməkdaşlıq alətləri.

Yeni Zelandiyanın e-elm infrastrukturu. NeSI (New Zealand eScience Infrastructure) hesablama tədqiqat infrastrukturu ölkənin Biznes, İnnovasiya və Məşğulluq Nazirliyi vasitəsilə universitet və tədqiqat institutlarını birləşdirir[7]. O, böyük hesablama və yaddaş resursları tələb edən tədqiqat layihələri üçün Yüksək məhsuldarlı hesablamalar, Hesablamalara elmi dəstək, Verilənlərin tədqiqi və Təlim xidmotlorini təqdim edir.

Məlumdur ki, yüksək məhsuldarlı hesablamalar və əlaqədar e-elm infrastrukturu müasir elmin zəruri tərkib hissələridir. NeSI ölkə əhəmiyyətli mürəkkəb məsələlərin həlli üçün yüksək xarakteristikalı texniki və proqram vasitələri təqdim edir, həmçinin təlim və dəstək üçün əlaqədar yüksək ixtisaslı mütəxəssisləri cəlb edir. Elm sahələri üzrə dünyanın təcrübəli ekspertlərindən təşkil olunmuş elmi komanda 
tədqiqatçılara hesablamalar üzrə elmi dəstək verir. NeSI qrupu platformalar və xidmətlərdən ən yaxşı şəkildə faydalanmaq üçün tədqiqatçıları dəstəkləyir və tədqiqat qrupları ilə aşağıdakı istiqamətlər üzrə birgə işlələri təşkil edir:

- elmi-tədqiqat proqramları kodlarının səmərəliliyinin artırılmasi;

- yaddaş və digər zəif yerlərin və ya giriş-çıxış qovşaqlarında problemlərin aradan qaldırılması;

- tədqiqatçıların və elmi proqram vasitələri mütəxəssislərinin bir-biri ilə əlaqələndirilməsi.

Yüksək məhsuldarlıqlı süperkompüterlərdə işləmək üçün tədqiqatçılar geniş spekterli proqram vasitələri və paketləri ilə təmin edilir. Bunlara bir qovşağın məhsuldarlığı, paralel iş, sazlama və korreksiya, əlaqələr, ölcmə, inteqrasiya və vizullaşdırma vasitələrini misal göstərmək olar.

\section{NӘTIC๐}

E-elmin formalaşması, istismarı və inkişafinda proqram mühəndisliyi mühüm rol oynayır. Dünyanın geniş maraq kəsb edən qabacıl e-elm layihələri üzrə aparılmış araşdırmalar buna əsas verir. Olavə vaxt və maliyyə sərf etmədən açıq kodlu proqram vasitələrindən istifadə etməklə ölkədə e-elmin daha səmərəli inkişafına nail olmaq olar.

\section{ӘDӘBIYYAT}

[1] Т.Х.Фаталиев, «Электронная наука: состояние и перспективы развития в Азербайджане», Телекоммуникации, 2016, №8, с.41-48.

[2] Globus Toolkit:, http://toolkit.globus.org/toolkit

[3] TeraGrid:, www.teragrid.org

[4] National Research Grid Initiative:, www.naregi.org/project/index_e.html

[5] GEANT.://www.geant.net

[6] European Grid Infrastructure:, www.egi.eu

[7] New Zealand eScience Infrastructure.:, www.nesi.org.

$\mathrm{Bu}$ iş Azorbaycan Respublikasının Prezidenti yanında Elmin Inkişafi Fondunun maliyya yardımı ila yerina yetirilmişdir - Qrant № EIF-2014-9(24)-KETPL-14/02/1 